\title{
OSOBOWOŚCIOWE UWARUNKOWANIA POSTAW PRZEDSIĘBIORCZYCH W UJĘCIU LOKALNYM NA PRZYKŁADZIE GMINY BRAŃSK
}

\section{Streszczenie}

Cel - Przedsiębiorcy stanowią niezwykle istotny element społeczeństwa, oddziałujący w znaczącym stopniu na rozwój i wzrost gospodarczy kraju. Dlatego też warto zastanowić się, jakie czynniki wpływają na niektóre jednostki, że podejmują decyzję o założeniu i prowadzeniu przedsiębiorstwa. Celem opracowania jest podjęcie próby identyfikacji cech osobowości charakteryzujących przedsiębiorców. Możliwe jest zatem postawienie hipotezy, iż występuje możliwość wskazania cech charakteru determinujących skłonność danej jednostki do założenia i prowadzenia działalność gospodarczej. W założeniu autora do tych cech zaliczyć można: kreatywność, wiedzę oraz odwagę.

Metodyka badania - W opracowaniu wykorzystano metodę opisowo-indukcyjną. Dokonano krytycznej analizy literatury przedmiotu oraz zaprezentowano wyniki badań własnych.

Wynik - W wyniku analizy odpowiedzi ankietowanych przedsiębiorców oraz dokonanego przeglądu literatury, można stwierdzić istotność znaczenia cech osobowości przedsiębiorcy przy rozpoczynaniu działalności gospodarczej oraz podczas dalszego prowadzenia działalności $\mathrm{w}$ badanej gminie.

Oryginalność/wartość - Przeprowadzona analiza pozwala na potwierdzenie postawionej hipotezy, jednakże identyfikacja istotności oraz znaczenia poszczególnych cech charakteru, przypisanych przedsiębiorcom, wymaga dalszych badań i analiz.

Słowa kluczowe: przedsiębiorczość, uwarunkowania przedsiębiorczości, determinanty przedsiębiorczości, postawy przedsiębiorcze

\section{PERSONAL DETERMINANTS OF ENTREPRENEURSHIP SETS IN THE LOCAL STAND ON THE EXAMPLE OF BRANSK COMMUNE}

\section{Summary}

Goal - Entrepreneurs constitute an extremely important element of society, affecting significantly the development and economic growth of the country. Therefore, it is worth considering what factors affect some individuals, that they make the decision to set up and run a business. In this article, the author focuses on factors related to the entrepreneur's personality. The aim of the study is to attempt to identify personality traits that characterize entrepreneurs. It is therefore possible to hypothesize that some character traits determine whether a person is able to set up and run a business. 
Research methodology - The study presents a critical analysis of the literature and the presentation of own research.

Score - As a result of the analysis of the responses of the surveyed entrepreneurs and the review of the literature, it is possible to determine the significance of the entrepreneur's personality traits when starting a business and during further business.

Originality /value - The analysis allows to confirm the hypothesis, however, the identification of the significance and importance of individual character traits assigned to entrepreneurs requires further research and analysis.

Keywords: entrepreneurship, conditions of entrepreneurship, determinants of entrepreneurship, entrepreneurial attitudes

DOI: $10.15290 /$ wpewbmn4.2020.03

\section{Wprowadzenie}

Przedsiębiorcy i prowadzona przez nich działalność gospodarcza ma znaczący wpływ na gospodarkę narodową. Osoby prowadzące własne przedsiębiorstwa przyczyniają się w znacznej mierze do wzrostu gospodarczego oraz do dynamicznych zmian w strukturze gospodarczej kraju. Są podstawowym motorem napędowym gospodarki. Potwierdzają to dane zbierane przez urzędy statystyczne. Wzrost gospodarczy, a także zmiany w strukturze gospodarki, spowodowane są głównie działalnością przedsiębiorców. W ostatnich latach można zaobserwować wzrost udziału przedsiębiorstw w tworzeniu PKB - z 71,1\% w 2008 roku do 74,0\% w 2015 roku, ponadto co druga złotówka $(49,9 \%)$ jest generowana przez firmy z sektora MSP, a mikroprzedsiębiorstwa mają największy udział w tworzeniu PKB - 30,5\% ${ }^{1}$.

Nie bez przyczyny obok kapitału, pracy i ziemi to właśnie przedsiębiorczość została uznana za czwarty czynnik produkcji. Przedsiębiorcy kształtują otaczające ich środowisko, wyznaczają kierunki rozwoju, tworzą nowe produkty oraz ciągle udoskonalają te, które już pojawiły się na rynku. Odgrywają istotną rolę w życiu społecznym, stają się wzorem do naśladowania, mają społeczne uznanie i szacunek. Bardzo często wspierają rozwój swojego najbliższego otoczenia, czyli miasta, gminy czy powiatu. Rozwijają nie tylko własną działalność, ale również za ich pośrednictwem zyskuje całe otoczenie.

Ponieważ przedsiębiorcy są niezwykle istotnym elementem społeczeństwa, warto zastanowić się, czy można zidentyfikować cechy charakteru im przypisane. Identyfikacja takich cech może w przyszłości pomóc w kształceniu przyszłych przedsiębiorców. Na potrzeby artykułu wykorzystana została krytyczna analiza literatury przedmiotu oraz przedstawione zostały wyniki badań własnych przeprowadzonych w gminie Brańsk. Upoważnione jest zatem postawienie hipotezy, iż możliwe jest wskazanie cech charakteru determinujących skłonność danej jednostki do założenia i prowadzenia działalności gospodarczej. Według autora, do tych cech

\footnotetext{
${ }_{1}$ Raport o stanie sektora matych $i$ średnich przedsiębiorstw $w$ Polsce, A. Skowrońska, A. Tarnawa (red.), PARP, Warszawa 2018, s. 5.
} 
zaliczyć można: kreatywność, wiedzę oraz odwagę. Wartością badawczą pracy jest próba ich identyfikacji. Każdy przedsiębiorca musi funkcjonować w określonych ramach prawnych oraz społecznych, przeprowadzone badanie ukazuje cechy osobowości przedsiębiorcy uważane za istotne w badanej gminie.

Przedsiębiorczość można zdefiniować jako zmienną ciągłą, której wartość związana jest $\mathrm{z}$ umiejętnością dostrzegania ludzkich potrzeb i wykorzystania ich jako okazji do stworzenia działalności gospodarczej²; może ujawnić się jako styl zachowania ściśle powiązany z cechami charakteru oraz postawami. Na potrzeby pracy oraz, przy uwzględnieniu wymagań przeprowadzonego badania, autor przyjmuje definicję przedsiębiorczości równoznaczną z prowadzeniem własnej działalności gospodarczej.

W literaturze przedmiotu znacznie częściej zwraca się uwagę na uwarunkowania zewnętrzne przedsiębiorczości ${ }^{3}$, czyli takie, które są związane głównie z bliższym bądź dalszym otoczeniem. Nie ulega wątpliwości, że elementy te są istotne ${ }^{4}$, jednakże istnieją jeszcze inne czynniki, uwarunkowane przede wszystkim wewnętrznymi predyspozycjami przedsiębiorcy. Są one ściśle związane z cechami osobowymi, motywacjami oraz wzorcami zachowań. Cechy te są trudne do identyfikacji ${ }^{5}$, pomimo tego wielu badaczy podejmowało próby analizy.

\section{Cechy osobowościowe warunkujące pojawianie się postaw przedsiębiorczych w społeczeństwie}

Nawiązania do czynników determinujących postawy przedsiębiorcze można odnaleźć u wielu badaczy np.: J.B. Say za główne cechy osoby przedsiębiorczej uważał zdolność do nadzoru oraz zarządzania ${ }^{6}$, natomiast A. Smith dostrzegał, że za całość odpowiada „moc twórcza”, którą posiada dana jednostka oraz skłonność do podejmowania ryzyka, jak i pomysłowość w tworzeniu nowych rozwiązań7. Torstein Veblen wyróżnia inteligencję techniczną przedsiębiorcy, czyli jego umiejętność do tworzenia czegoś nowego, innowacyjnego ${ }^{8}$. Joseph A. Schumpeter wskazuje na „ducha przedsiębiorczości”, który jawi się jako pomysłowość, umiejętność wyłamania się z występującego w danych czasach schematu, przejęcie

\footnotetext{
2 R. Studenski, A. Studenska, Predykatory przedsiębiorczości, [w:] Przedsiębiorczość źródła i uwarunkowania psychologiczne, Z. Ratajczak (red.), Warszawa 2012, s. 298-209.

3 H.G. Adamkiewicz-Drwiłło, Uwarunkowania rozwoju przedsiębiorczości. Determinanty $i$ narzędzia zdobywania przewagi konkurencyjnej, PWN, Warszawa 2007, s. 17-20.

${ }^{4}$ K. Krajewski, Determinanty rozwoju małych i średnich przedsiębiorstw, IPiS, Warszawa 1999, cyt. za: J. Pawlak, Wybrane psychologiczne determinanty przedsiębiorczości absolwentów w świetle koincydencji teorii rozwoju, „Nierówności Społeczne a Wzrost Gospodarczy” 2015, nr 42(2), s. 402.

5 T. Kraśnicka, Koncepcja rozwoju przedsiębiorczości ekonomicznej i pozaekonomicznej, Wydawnictwo Akademii Ekonomicznej w Katowicach, Katowice 2002, s. 59.

6 T. Piecuch, Przedsiębiorczość podstawy teoretyczne, C.H. Beck, Warszawa 2013, s. 86.

7 R.L. Heilbroner, Wielcy ekonomiści: Czasy, życie, idee, Warszawa 1993, s. 59.

8 J. Górski, W. Sierpiński, Historia powszechnej myśli ekonomicznej 1870-1950, Warszawa 1987, s. 16.
} 
inicjatywy, pokonywanie ograniczeń i barier ${ }^{9}$. Izrael Kirzner przypisuje przedsiębiorcom specyficzne umiejętności, szczególny rodzaj czujności, zdolność przezwyciężenia tradycji, unikanie schematów i rutyny, indywidualną umiejętność dostrzegania szans, których inni nie zauważają, umiejętności analizy i wskazywania miejsc, gdzie nowe produkty mogą stać się bardziej wartościowe, a nowe metody produkcji mogą przynieść duże zyski ${ }^{10}$.

Wzrost zainteresowania badaczy problematyką przedsiębiorczości pojawił się w drugiej połowie XX wieku ${ }^{11}$. Szczególną uwagę skierowano wówczas na poszukiwanie profilu osobowości przedsiębiorcy ${ }^{12}$. Przedsiębiorczość wiązano z cechami podmiotowymi ${ }^{13}$, osobowością ${ }^{14}, \mathrm{w}$ tym badano różnice pomiędzy menadżerami a przedsiębiorcami ${ }^{15}$, związki z kulturą i religią ${ }^{16}$. Porównywano wpływ postaw, intencji ${ }^{17}$ oraz wiedzy przedsiębiorców ${ }^{18}$. Poszukiwano konkretnych cech wyróżniających przedsiębiorców, takich jak: kreatywność ${ }^{19}$, umiejętność radzenia sobie w sytuacjach trudnych ${ }^{20}$, utrzymywanie obranego kierunku działań, radzenie sobie w sytuacjach sukcesu i porażki, umiejętność przekraczania granic wyznaczanych

\footnotetext{
9 E. Otoliński, Istota i kreowanie przedsiębiorczości, „Przegląd organizacji” 1996, nr 9, s. 25.

${ }^{10}$ I. Kirzner, The Entrepreneurial Process, „The Environment of Entrepreneurship” 1984, s. 41.

${ }^{11}$ R. Studenski, A. Studenska, Predykatory..., s. 193-194.

${ }_{12}$ T. Gruszecki, Przedsiębiorca w teorii ekonomii, Cedor, Warszawa 1994, s. 45.

${ }^{13}$ D.C. McClelland, The Achieving Society, Princeton, Van Nostrand 1961, s. 159-162; J.W. Carland, F. Hoy, W.R. Boulton, J.C. Carland, Differentiating Small Business Owners from Entrepreneurs,
} „Academy of Management Review” 1984, no. 9, s. 354-359.

${ }^{14}$ T. Begley, D. Boyd, Psychological Characteristics Associated with Performance in Entrepreneurial Firms and Smaller Businesses, ,Journal of Business Venturing” 1987, vol. 2, s. 19-93; B. Bird, Entrepreneurial Behavior, Glenview, Scott, Foresman \& Company, Illinois 1989, s. 509-520.

${ }^{15}$ D. Turek, Przedsiębiorca a pracownik przedsiębiorczy. Podobieństwa i różnice profili kompetencyjnych $i$ ich implikacje dla procesów zarządzania. Perspektywa charakterystyk podmiotowych, [w:] Potencjał ludzki w rozwoju przedsiębiorczości indywidualnej i korporacyjnej, B. Jamka (red.), Warszawa 2012, s. 33-57.

${ }^{16}$ R.D. Hisrich, Entrepreneurship/Intrapreneurship, „American Psychologist” 1990, vol. 45, no. 2, s. 209-222; R.G. McGrath, I.C. McMillan, S. Sheinberg, Elitists, risk-takers, and rugged and non-entrepreneurs, ,Journal of Business Venturing” 1992, no. 7, s. 115-135.

17 J.J. Chrisman, Estimating The Extent Entrepreneurial Intentions Become Reality: A Note, United States Association for Small Business and Entrepreneurship, „Annual National Conference” 1997, no. 14, cyt. za: R. Studenski, A. Studenska, Predykatory przedsiębiorczości, [w:] Przedsiębiorczość źródta i uwarunkowania psychologiczne, Z. Ratajczak (red.), Warszawa 2012, s. 194; P. Davidsson, Determinants of Entrepreneurial Intentions, RENT IX Workshop in Entrepreneurship, Research, Piacenza, Italy 1995, https://www.researchgate.net/publication/27464379_Determinants_Of_ Entrepreneurial_Intentions [dostęp: 20.02.2018]; E.A. Dionco-Adetayo, Factors Influencing Attitude of Youth Towards Entrepreneurship, „International Journal of Adolescence and Youth” 2006, vol. 13 , no. 1/2, s. 127-140.

${ }^{18}$ C. Batstone, G. Perry, P. Polsaram, Thai Service Sector Smes: Is Tacit Knowledge the Key Entrepreneur Success Characteristics?, 16th Annual Conference of Small Enterprise Association of Australia and New Zealand, 2003, http://www.cric.com.au/seaanz/resources/60Abstract.pdf [dostęp: 25.02.2018].

${ }^{19}$ J.E. Perry-Smith, C.E. Shalley, The Social Side of Creativity: A Scientific and Dynamic Social Network Perspective, „The Academy of Managenent Review” 2003, vol. 28, no. 1, s. 89-106.

${ }^{20}$ R.E. Franken, Psychologia motywacji, Gdańskie Wydawnictwo Psychologiczne, Gdańsk 2005, s. 425-427. 
przez konformizm ${ }^{21}$. Badaniu poddawano umiejętności i możliwości osiągania sukcesu, indywidualne zdolności do dostrzegania szans oraz realizacji poszczególnych zadan ${ }^{22}$. Analizowano potrzebę osiągnąć i autonomii23 ${ }^{23}$ a także zdolności intelektualne ${ }^{24}$, umiejętność koncentracji, poziom motywacji, zdolność abstrakcyjnego myślenia ${ }^{25}$. Wśród cech charakteryzujących przedsiębiorców znalazły się również: wiara w siebie, optymizm, otwartość na innych i zachodzące zmiany ${ }^{26}$, wyobraźnia, opanowanie, samodzielność, samowystarczalność, asertywność, umiejętności pracy w zespole ${ }^{27}$, wykraczanie poza ustalone schematy i ograniczenia ${ }^{28}$, otwartość na zmiany, gotowość do innowacji ${ }^{29}$, umiejętność adaptacji do panujących warunków, wewnętrzną sterowność, silny charakter ${ }^{30}$ oraz skłonność do podejmowania ryzyka $^{31}$. Do wyjaśnienia zachowań przedsiębiorczych wykorzystano teorię umiejscowienia kontroli3 ${ }^{32}$, w której wskazywano, iż przedsiębiorcy są przekonani o tym, że sami decydują o swoim życiu, a nie są zdani na los. W licznych publikacjach, dotyczących cech charakteryzujących przedsiębiorców, wskazuje się na ponoszenie odpowiedzialności za skutki swoich przedsięwzięć oraz posiadanie przez przedsiębiorców świadomości odniesienia sukcesu, bądź porażki³3 ${ }^{33}$ Wykazują oni

${ }^{21}$ A. Strzałecki, Transgresja polskich menedżerów $w$ warunkach transformacji ustrojowej, [w:] Człowiek wobec wyzwań i dylematów współczesności, A. Aranowska, M. Goszczyńska (red.), Warszawa 2006, s. 107-108.

${ }^{22}$ G. Cacciotti, J.C. Hayton, Fear and Entrepreneurship: A Review and Research Agenda, „International Journal of Management Reviews” 2015 vol. 17, no. 2, s. 44-45.

${ }^{23}$ H.R. Brockhaus, Risk Taking Propensity of Entrepreneurs, „Academy of Management Journal” 1989, vol. 23, no. 3, s. 23-25; J.W. Carland, F. Hoy, W.R. Boulton, J.C. Carland, Differentiating Small Business..., s. 354-359; A. Strzałecki, Creativity in Design. General Model and Its Verification, „Technological Forecasting and Social Change" 2000, no. 64(2/3), s. 241-260; A. Strzałecki, D. Czołak, Osobowościowe i temperamentne wyznaczniki osiągania sukcesu w przedsiębiorczości, „Przegląd Psychologiczny" 2005, nr 48(2), s. 133-151.

${ }^{24}$ E. Osborn, K.M. Słomczyński, Open for Business. The Persistent Entrepreneurial Class in Poland, IFiS Publishers, Warszawa 2005, s. 627-630; A. Strzałecki, Transgresja polskich menedżerów..., s. 107-108.

${ }^{25}$ A.P.Wiatrak, Pojęcie przedsiębiorczości, jej cele i rodzaje, [w:] Uwarunkowania rozwoju przedsiębiorczości - szanse i zagrożenia, K. Jaremczuk (red.), Tarnobrzeg 2003, s. 27.

${ }^{26}$ E. Grzegorzewska-Mischka, Współczesne uwarunkowania rozwoju przedsiębiorczości w Polsce, Oficyna Wydawnicza SGH, Warszawa 2010, s. 25-30.

${ }^{27}$ A. Ostromecki, Wywoływanie postawy twórczej w procesie rozwoju przedsiębiorczości, [w:] Uwarunkowania przedsiębiorczości - aspekty ekonomiczne i antropologiczno-społeczne, K. Jeremczuk (red.), Tarnobrzeg 2006, s. 694.

${ }^{28}$ T. Tyszka, Psychologia zachowań ekonomicznych, PWN, Warszawa 1997, s. 106.

${ }^{29}$ A. Strzałecki, Style twórczego zachowania $w$ przedsiębiorczości, [w:] Innowacyjna przedsiębiorczość: teorie, badania, zastosowania praktyczne, perspektywa psychologiczna, A. Strzałecki (red.), Warszawa 2011, s. 86-87.

${ }^{30}$ A. Domurat, Przedsiębiorczość a kreatywność i innowacyjność, [w:] Innowacyjna przedsiębiorczość: teorie, badania..., s. 286-288.

${ }^{31}$ Jr. W.H. Steward, P.L. Roth, Risk Propensity Differences Between Entrepreneurs and Managers: A Meta-Analytic Revive, ,Journal of Applied Psychology” 2001, no. 86, s. 146-148.

${ }^{32}$ J.B. Rotter, Generalized Expectancies for Internal Versus External Control of Reinforcement, „Psychological monographs: General and applied" 1966, no. 80(1), s. 25-29.

${ }^{33}$ D.B. Audretsch, M. Obschonka, S.D. Gosling, J. Potter, A New Perspective On Entrepreneurial Regions: Linking Cultural Identity with Latent and Manifest Entrepreneurship, „Small Business Economics" 2016, vol. 47, no. 2, s. 687-690. 
zdolności inspirowania innych do działania oraz nie uznają ograniczeń wynikających z istniejących struktur ${ }^{34}$.

Najbardziej obszerne badania można odnaleźć na temat podejmowania ryzyka przez osoby posiadające cechy identyfikowane jako przedsiębiorcze. Badania prowadzone przez R. Cotona oraz G. Udela wskazywały, iż przedsiębiorcy wolą zadania konkretne, ryzykowne, wymagające kreatywności, elastyczności, dysponują umiejętnością odnalezienia się w sytuacjach kryzysowych i problemowych, natomiast charakteryzują się niechęcią do działań schematycznych ${ }^{35}$. Jeffry A. Timmons wyróżnił sześć fundamentalnych właściwości osoby przedsiębiorczej. Zaliczył do nich: dynamizm działaniowy, zdolność przewodzenia, umiejętność dostrzegania szans, umiejętność działania w warunkach ryzyka i niepewności, kreatywność, samodzielność i zdolność przystosowania do panujących warunków, wewnętrzną motywację ${ }^{36}$. Natomiast B. Karlof sformułował szeroki zakres cech, którymi powinien charakteryzować się przedsiębiorca ${ }^{37}$. Zaliczył do nich samodzielne podejmowanie decyzji, potrzebę widzenia postępów swoich działań, oczekiwanie konstruktywnej krytyki bądź pochwały, aktywny udział w działalności przedsiębiorstwa, duże wymaganie od siebie i od swoich współpracowników. Lech Milian wychodzi z założenia, iż część tych cech jest wrodzona, a część nabyta. Cechy wrodzone wspomagają te nabyte w toku kształcenia oraz na odwrót. Jedne uzupełniają drugie i pozwalają na ukształtowanie się postaw przedsiębiorczych ${ }^{38}$. Wśród cech wrodzonych znajdują się między innymi: intuicja, szybka ocena sytuacji, przewidywanie przyszłych wydarzeń. Milian uważa, że cechy te można wzmocnić poprzez naukę, ale można je również wykształcić u osób nieposiadających ich. Uzyskać to można poprzez odpowiednie techniki i metody nauczania, a przede wszystkim przez chęć, wytrwałość i pracowitość danej osoby. Wychodząc z takiego założenia można dojść do wniosku, że przedsiębiorczości można się nauczyć - nie jest to zestaw umiejętności do końca wrodzony ${ }^{39}$. Wolfgang Maderthaner stworzył zestaw czynników, które mogą spowodować zmianę przeciętnego człowieka w przedsiębiorcę $^{40}$. Można zaliczyć do nich: motywację, radość z pracy, osobiste zaangażowanie, inicjatywę, swobodę decyzji, gotowość do podejmowania ryzyka, dążenie

\footnotetext{
${ }^{34}$ C. Kolb, M. Wagner, Crowding in or Crowding Out: The Link Between Academic Entrepreneurship and Entrepreneurial Traits, „The Journal of Technology Transfer” 2015, vol. 40, no. 3, s. 389-406.

${ }^{35}$ D.L. Hull, J.J. Bosley, G.G. Udell, Renewing the Hunt for The Heffalump: Identifying Potential Entrepreneurship by Personal Characteristics, „Journal of Small Business Management” 1980, vol. 18, no. 1, s. 268-275.

${ }^{36}$ J.C. Carland, J.W. Carland, W.H. Stewart, Seeing What's Not There: The Enigma of Entrepreneurship, ,Journal of Small Business Strategy” 1996, vol. 7, no. 1, s. 17-18.

${ }^{37}$ W. Szewczyk, Encyklopedia psychologii, Wydawnictwo Fundacja „Innowacja”, Warszawa 1998, s. 468.

${ }^{38}$ L. Milian, Przedsiębiorczość i przedsiębiorstwo turystyczne. Socjologiczne uwarunkowania sukcesu, Wydawnictwo Politechniki Częstochowskiej, Częstochowa 2000, s. 10-17.

${ }^{39}$ T. Kraśnicka, Uwarunkowania rozwoju przedsiębiorczości - podejście wielowymiarowe, [w:] Przedsiębiorstwo w procesie transformacji, K. Jaremczuk (red.), Przemyśl 2000, s. 57.

${ }^{40}$ H. Pietras, Przedsiębiorczość w warunkach gospodarki rynkowej, [w:] Przedsiębiorczość w teorii i praktyce gospodarczej, W. Grzybowski (red.), Lublin 1994, s. 94.
} 
do osiągnięcia najwyższej jakości pracy, świadomość kosztów, świadomą odpowiedzialność za pracowników niższych szczebli oraz zorientowanie na konkurencję.

Wśród psychologów zainteresowanie skierowanie zostało na moment podjęcia decyzji i rozpoczęcie konkretnego działania związanego z założeniem działalności gospodarczej ${ }^{41}$. W tym momencie zaobserwować można pojawianie się wielu wymagających i długookresowych działan, pełnego zaangażowania, podjęcia ryzyka wynikającego z nowych, niepewnych warunków ${ }^{42}$. Przedsiębiorcy muszą wykazać się umiejętnością połączenia sprzecznych umiejętności, wytrwałego realizowania założonych celów oraz elastycznego dopasowania się do zmiennych uwarunkowań. Wykazano, że osoby rozpoczynające prowadzenie działalności gospodarczej różnią się od ogółu społeczeństwa w podobnym wieku ${ }^{43}$. Cechują się zrównoważeniem emocjonalnym, optymizmem, ambicją, aktywnością, otwartością oraz kreatywnością i pracowitością. Może to być związane z odmiennością pracy przedsiębiorców od zadań wykonywanych $\mathrm{w}$ innych profesjach ${ }^{44}$. Praca przedsiębiorcy odbywa się głównie w zmiennym otoczeniu, w którym nieustanie muszą przekraczać granice narzuconych systemów, ciągle poszukiwać zasobów oraz są zmuszeni do osiągania optymalnych rezultatów. Badanie przeprowadzone przez J.A. Welsha i J.F. Whita wskazało na 11 cech, które przyczyniają się do podjęcia decyzji o rozpoczęciu działalności gospodarczej. Do tych cech należą: potrzeba kierowania, wiara we własne siły, pragnienie działania, dobre zdrowie, świadomość konsekwencji działania i roli statusu społecznego, wysokie zdolności koncepcyjne, realizm, stabilność emocjonalna, podejście podmiotowe do stosunków międzyludzkich oraz umiejętność podejmowania wyzwań ${ }^{45}$. Dalsze badania dotyczące cech charakteryzujących przedsiębiorców, prowadzone przez N.C Churchila, wykazały, że część tych wartości traci na znaczeniu, gdy przedsiębiorstwo zaczyna osiągać sukces i rozpoczyna się jego wzrost. Czynniki te są ważne tylko podczas rozpoczynania działalności, a wraz z rozwojem i sukcesem firmy odgrywają coraz mniejszą rolę ${ }^{46}$. Wynika z tego, że cechy niezbędne w początkowej fazie tworzenia przedsiębiorstwa mogą okazać się zbędne lub nawet utrudniające działanie w innych fazach działania danej firmy na rynku.

\footnotetext{
${ }^{41} \mathrm{~J}$. Pawlak, Wybrane psychologiczne determinanty przedsiębiorczości absolwentów w świetle koincydencji teorii rozwoju, „Nierówności Społeczne a Wzrost Gospodarczy” 2015, nr 42(2), s. 402-403.

${ }^{42}$ M. Łaguna, Przekonania na własny temat a aktywność celowa. Badania nad przedsiębiorczościa, Gdańskie Wydawnictwo Psychologiczne, Gdańsk 2010, s. 21.

${ }^{43}$ M. Kaczmarek, Cechyosobowości jako predykator motywacji i skuteczności działań przedsiębiorczych, „Problemy zarządzania” 2014, t. 12, nr 1(45), s. 185-186; H. Zhao, S.E. Seibert, G.T. Lumpkin, The Relationship of Personality to Entrepreneurial Intentions and Performance. A Meta-Analytic Review, „Journal of Management” 2010, no. 36, s. 381-403.

${ }^{44}$ R. Studenski, A. Studenska, Predykatory..., s. 108-109.

${ }^{45}$ T. Kraśnicka, Koncepcja rozwoju przedsiębiorczości ekonomicznej i pozaekonomicznej, Wydawnictwo Akademii Ekonomicznej w Katowicach, Katowice 2002, s. 93-95.

${ }^{46}$ R.H. Brockhaus, P.S. Horowitz, The Psychology of Entrepreneur, [w:] The Art. and Science of Entrepreneurship, D. Sexton, R. Smilor (red.), Massachusetts 1986, s. 33-34.
} 
W prowadzeniu działalności gospodarczej potencjał psychologiczny, który posiada dana jednostka, jest podstawą do rozpoczęcia funkcjonowania na rynku. Indywidualna kombinacja cech danego przedsiębiorcy oraz jego wiedzy, umiejętności, a także energii, wyzwala impuls do rozpoczęcia działania oraz decyduje o odniesieniu przez niego sukcesu lub porażki ${ }^{47}$. W trakcie analizy literatury można znaleźć wiele cech, które uważa się za wyróżniki predysponujące jednostkę do zachowań przedsiębiorczych. Indywidualne cechy danej jednostki kształtują profil, zakres oraz obszar działalności, a w późniejszym okresie determinują możliwości rozwoju działalności gospodarczej. To wpływ tych cech będzie warunkował odporność na stres, radzenie sobie w sytuacjach trudnych, a czasem nawet uważanych za sytuacje bez wyjścia. Kombinacja odpowiednich cech doprowadza do osiągnięcia sukcesu.

\section{Materiał i metoda badawcza}

Przeprowadzona analiza miała na celu zbadanie poglądów oraz opinii osób prowadzących działalność gospodarczą na temat czynników wpływających na podejmowanie decyzji o prowadzeniu działalności gospodarczej. Wyniki przedstawione w artykule są fragmentem obszerniejszej analizy obejmującej determinanty przedsiębiorczości. Badanie zostało przeprowadzone na przełomie lutego i marca 2016 roku na terenie gminy Brańsk. Jest to gmina wiejska, położona w województwie podlaskim, w powiecie bielskim. Teren gminy zamieszkuje 6027 mieszkańców. Kobiety stanowią około $48 \%$ mieszkańców, a mężczyźni około 52\%. Gmina zajmuje powierzchnię $227 \mathrm{~km}^{2}$. W jej skład wchodzą 43 sołectwa. Gmina stanowi 16,41\% powierzchni powiatu. Użytki rolne zajmują ponad $78 \%$ powierzchni, natomiast użytki leśne stanowią $15 \%$. Obszary leśne to ponad 3,5 tys. hektarów ${ }^{48}$. Na terenie gminy Brańsk przeważająca liczba mieszkańców zajmuje się rolnictwem. Oprócz rolnictwa na terenie gminy funkcjonują 148 podmioty gospodarcze ${ }^{49}$. Osoby prowadzące własny biznes stanowią zaledwie $2 \%$ ogółu mieszkańców gminy.

Badanie przeprowadzone zostało bezpośrednio przez ankietera w formie ankiety jednokrotnego wyboru. Dobór próby badawczej był losowy, dotyczył osób prowadzących działalność gospodarczą na obszarze gminy Brańsk. W badaniu wzięło udział 60 przedsiębiorców, czyli ponad $40 \%$ wszystkich przedsiębiorców działających na terenie gminy, z czego większość stanowili mężczyźni - 67\%, natomiast kobiety $-33 \%$.

Ankietowani przedsiębiorcy deklarowali wykształcenie średnie - 44\%, wyższe $-33 \%$, zawodowe $-20 \%$ oraz podstawowe $-3 \%$, ostatnią grupę stanowili wyłącznie mężczyźni. Ankietowani zostali podzieleni na pięć grup wiekowych. W grupie wiekowej 45-55 lat znajdowało się 32\% respondentów, w grupie 25-34 lat -25\%, 56-64

\footnotetext{
${ }^{47}$ T. Piecuch, Przedsiębiorczość podstawy teoretyczne, C.H. Beck, Warszawa 2013, s. 20-21.

${ }^{48}$ Stan na 25.02.2016 według danych Głównego Urzędu Statystycznego [dostęp: 25.02.2016].

${ }^{49}$ Stan na 25.02.2016 według danych Centralnej Ewidencji Działalności Gospodarczej [dostęp: 25.02.2016].
} 
lat-18\%, 34-44 lat-17\%. Najmłodsza grupa wiekowa 18-24 stanowiła zaledwie $8 \%$ badanych.

Na potrzeby ankiety, oraz biorąc pod uwagę specyfikę gminy, dokonano podziału przedsiębiorstw ze względu na wielkości. Klasyfikacja składała się z przedsiębiorstw: jednoosobowych (niezatrudniających pracowników), małych (zatrudniających od 1 do 10 pracowników) oraz średnich (zatrudniających powyżej 10 pracowników). Zgodnie z tym podziałem udział w ankiecie wzięło: $51 \%$ przedsiębiorców prowadzących działalność jednoosobową, 30\% stanowiły firmy małe oraz $19 \%$ średnie.

Wykres 1.

Struktura działalności ankietowanych przedsiębiorców (w \%)

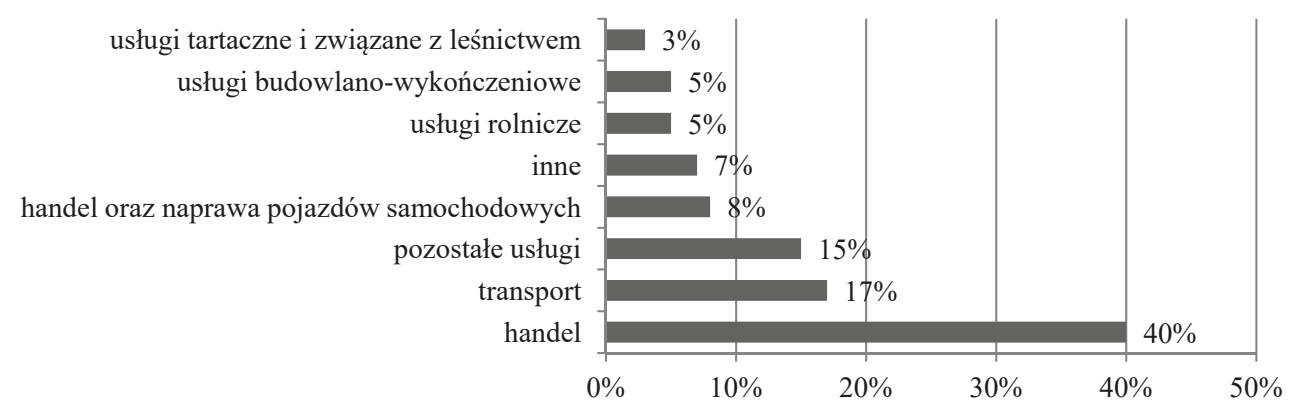

Źródło: wyniki badań własnych.

Ankietowani przedsiębiorcy prowadzą głównie działalność w zakresie handlu $-40 \%$, transportu $-17 \%$, usług - $15 \%$, handlu i naprawy pojazdów samochodowych $-8 \%$, usług rolniczych $-5 \%$, usług budowlano-wykończeniowych $-5 \%$ oraz usług tartacznych i związanych z leśnictwem - 3\%.

Przeważająca część ankietowanych, bo aż $80 \%$ przedsiębiorców, wskazało na to, że prowadzi pierwszą działalność gospodarczą. Natomiast 17\% stanowią osoby, które prowadzą działalność po raz drugi. Więcej jak dwie próby prowadzenia własnej firmy deklarowało 3\% ankietowanych. Druga próba prowadzenia działalności gospodarczej była wskazywana przez respondentów posiadających wykształcenie średnie $-19 \%$, zawodowe $-17 \%$ oraz wyższe $-15 \%$. Natomiast więcej jak dwie próby podejmowania działalności gospodarczej były wskazywane przez ankietowanych przedsiębiorców posiadających wykształcenie wyższe $-5 \%$ i średnie $-4 \%$. Liczba prób prowadzenia własnej działalności gospodarczej wśród przedsiębiorców biorących udział w badaniu wzrasta wraz z poziomem wykształcenia. Może to świadczyć o pozytywnym wpływie edukacji na rozwój niektórych cech, takich jak wytrwałość, chęć podejmowania ryzyka oraz dążenie do postawionego celu, pomimo pojawiających się przeszkód. Potwierdza to twierdzenie postawione przez L. Miliana o możliwości wykształcenia pewnych cech przedsiębiorczych poprzez odpowiednią edukację. 


\section{Wyniki przeprowadzonych badań}

Przeprowadzone badania pozwoliły na wskazanie cech charakteru, według respondentów wyróżniających przedsiębiorców oraz w znacznym stopniu wpływających korzystnie na prowadzenie działalności gospodarczej. W opinii ankietowanych przedsiębiorców pomysłowość i kreatywność - 32\% oraz pracowitość - 30\% zostały uznane za najważniejsze elementy osobowości mające istotne znaczenie przy prowadzeniu firmy. Za mniej istotne uznane zostały: odwaga $-15 \%$, wiedza $10 \%$, pewność siebie $-8 \%$, inteligencja $-3 \%$ oraz inne cechy $-2 \%$. Zróżnicowanie zaobserwować można również w podziale na płeć ankietowanych, jednakże mała grupa kobiet biorąca udział w ankiecie może fałszować wynik. Kobiety znacznie częściej wskazywały pomysłowość i kreatywność - ponad 50\% ankietowanych pań typowało tę odpowiedź. Mężczyźni natomiast najczęściej wskazywali na pracowitość - 33\% oraz na pomysłowość i kreatywność - 23\%. Takie odpowiedzi mogą być związane z profilem oraz specyfiką prowadzonej działalności: mężczyźni głównie specjalizują się w zawodach wymagających pracy fizycznej, natomiast kobiety stawiają na odpowiednie podejście do klienta.

Tabela 1 .

Cechy charakteru istotne przy prowadzeniu działalności gospodarczej w opinii badanych przedsiębiorców (w \%)

\begin{tabular}{l|c}
\multicolumn{1}{c}{ Odpowiedzi } & Wskazania ankietowanych \\
\hline Pomysłowość i kreatywność & $32 \%$ \\
\hline Pracowitość & $30 \%$ \\
\hline Odwaga & $15 \%$ \\
\hline Wiedza & $10 \%$ \\
\hline Pewność siebie & $8 \%$ \\
\hline Inteligencja & $3 \%$ \\
\hline Inne & $2 \%$ \\
\hline
\end{tabular}

Źródło: wyniki badań własnych.

Pracowitość była najczęściej wskazywana w grupach wiekowych 18-24 lat $40 \%$, 35-44 lat-40\%, 45-55 lat-32\% oraz pośród ankietowanych posiadających wykształcenie podstawowe - $50 \%$ i średnie - $42 \%$, jak i przez przedsiębiorców prowadzących działalność jednoosobową - 42\%. Natomiast pomysłowość i kreatywność wskazywana była najczęściej przez respondentów zaliczanych do grup wiekowych 18-24 lat $-40 \%$, 25-34 lat - 33\%, 45-55 lat - 32\% oraz deklarujących wykształcenie wyższe $-40 \%$ i przez przedsiębiorców zatrudniających do 10 pracowników $-44 \%$. Pomysłowość, kreatywność oraz pracowitość to w opinii ankietowanych najważniejsze elementy osobowości przedsiębiorcy. Mają one korzystny wpływ na prowadzoną działalność gospodarczą. Cechy te umożliwiają postawienie przed sobą 
i przedsiębiorstwem celów oraz konsekwentne osiąganie zamierzonych rezultatów. Stanowią nieocenioną pomoc, gdy pojawiają się problemy, stanowią źródło wsparcia i motywują do walki z przeciwnościami. Związane są również ze zdolnościami tworzenia nowych rozwiązań, patentów czy innowacji, które umożliwiają utrzymanie się na rynku, a także predysponują do zdobycia przewagi konkurencyjnej. Zaobserwować można również zróżnicowanie odpowiedzi w zależności od poziomu wykształcenia ankietowanych. Przedsiębiorcy deklarujący wykształcenie wyższe znacznie częściej typowali pomysłowość i kreatywność, co może również wskazywać na korzystny wpływ edukacji. Osoby takie mają znacznie szerszą perspektywę, dostrzegają więcej szans oraz zagrożeń, a także rozwinęły w sobie umiejętności, które pozwalają na dostrzeganie nowych rynków zbytu, sposobów pozyskiwania klientów czy zdobywania przewagi konkurencyjnej.

Przedsiębiorcom zostało zadane pytanie dotyczące elementów osobowości, które utrudniają bądź uniemożliwiają prowadzenie działalności gospodarczej. W opinii ankietowanych do takich cech można zaliczyć: brak motywacji do działania $-27 \%$, brak umiejętności podejmowania ryzyka - 23\%, brak kreatywności $20 \%$, brak wiedzy i umiejętności - $15 \%$, nadmierną ambicję - 10\%, brak wytrwałości $-2 \%$ oraz inne cechy $-3 \%$.

Tabela 2 .

Elementy osobowości utrudniające prowadzenie działalności gospodarczej w opinii badanych przedsiębiorców (w \%)

\begin{tabular}{l|c}
\hline \multicolumn{1}{c|}{ Odpowiedzi } & Wskazania ankietowanych \\
\hline Brak motywacji & $27 \%$ \\
\hline Brak umiejętności podejmowania ryzyka & $23 \%$ \\
\hline Brak kreatywności & $20 \%$ \\
\hline Brak wiedzy i umiejętności & $15 \%$ \\
\hline Nadmierna ambicja & $10 \%$ \\
\hline Inne & $3 \%$ \\
\hline Brak wytrwałości & $2 \%$ \\
\hline
\end{tabular}

Źródło: wyniki badań własnych.

Brak motywacji do działania wskazywany był najczęściej przez ankietowanych przedsiębiorców w przedziale wiekowym 25-34 lat - 33\% i 45-55 lat - 26\% oraz przez respondentów posiadających wykształcenie zawodowe $-33 \%$, średnie $-31 \%$, jak również zatrudniających do 10 pracowników - 33\%. Nadmierna ambicja jest cechą utrudniającą prowadzenie działalności w opinii ankietowanych w przedziale wiekowym 18-24 lat - 40\%. Natomiast najstarsza grupa wiekowa 56-64 lat - 36\%, wskazuje na brak umiejętności podejmowania ryzyka. Najrzadziej wskazywaną cechą, która w opinii przedsiębiorców nie wpływa zbyt negatywnie na prowadzenie działalności gospodarczej, uznać można brak wytrwałości (2\%). 
Wielokrotnie wskazywane wśród respondentów cechy to: brak motywacji do działania, brak umiejętności podejmowania ryzyka oraz brak kreatywności. Ankietowani słusznie zauważyli, iż brak umiejętności podejmowania ryzyka istotnie uniemożliwia prowadzenie przedsiębiorstwa. Przy prowadzeniu działalności umiejętność taka jest niezbędna i jest nieodzownym elementem wpisanym w funkcjonowanie firmy. Brak motywacji do działania oraz brak kreatywności wyklucza jakąkolwiek szansę przetrwania przedsiębiorstwa w czasie kryzysu, bądź w przypadku zaistnienia innych trudności.

Wśród odpowiedzi respondentów można dostrzec wiele elementów, które mają wpływ na przedsiębiorców oraz na podejmowanie przez nich decyzji o prowadzeniu działalności gospodarczej. Obok czynników determinujących przedsiębiorczość można znaleźć zarówno te wynikające z otoczenia przedsiębiorcy, jak i te dotyczące samej osoby przedsiębiorcy. Trudno jest jednoznacznie wskazać na cechy uniwersalne i będące bezsprzecznie predykatorami przedsiębiorczości, jednak z dużym prawdopodobieństwem można zaliczyć do nich: pomysłowość, kreatywność, pracowitość oraz motywację do działania.

\section{Podsumowanie}

Do czynników determinujących przedsiębiorczość zaliczyć można wiele elementów: zarówno te związane z otoczeniem przedsiębiorcy, jak i te dotyczące cech osobowych. Niemniej jednak trudno jest wskazać jednoznacznie na cechy, które oddziałują z całą pewnością na każdego przedsiębiorcę. Mnogość prowadzonych, przez wielu naukowców różnych dziedzin, na przestrzeni wielu lat badań, pozwala jednak na stwierdzenie z całą pewnością, że cechy charakteru pełnią istotną rolę podczas prowadzenia i zakładania działalności gospodarczej przez przedsiębiorców.

Ankietowani przedsiębiorcy uznali uwarunkowania osobowościowe jako element, który wpływa na prowadzenie działalności gospodarczej. Przeprowadzone badania pokazują, że przedsiębiorcy dostrzegają i doceniają rolę osobowości i cech. Do najważniejszych cech charakteru, w opinii ankietowanych przedsiębiorców, można zaliczyć pomysłowość, kreatywność oraz pracowitość. Cechy te były wskazywane również u badaczy takich jak J.A. Schumpeter oraz W. Maderthaner, a także u wielu innych. Można zatem wysunąć wniosek, że podobne cechy będą występować i charakteryzować przedsiębiorców niezależnie od uwarunkowań społecznych, kulturowych oraz bez względu na narodowość.

Analizując poziom wykształcenia ankietowanych przedsiębiorców obserwuje się, że wraz ze wzrostem wykształcenia następuje wzrost liczby prób zakładania działalności gospodarczej oraz wzrost wskazań na pomysłowość i kreatywność. Zdaje się to potwierdzać L. Milian, pisał bowiem, że wraz ze wzrostem poziomu wiedzy następuje rozwój niektórych cech przydatnych przy prowadzeniu działalności gospodarczej. Osoby deklarujące wyższe wykształcenie posiadają znacznie szerszą umiejętność analizy danej sytuacji, dostrzegają więcej szans rynkowych 
oraz możliwości działania w trudnych okolicznościach. Cechują się większym optymizmem, wytrwałością oraz chęcią podejmowania ryzyka i dążenia do postawionego celu pomimo pojawiających się przeszkód.

Przeprowadzone badania własne pozwalają na wyciągnięcie wniosku, iż cechy charakteru są nieodzownym elementem towarzyszącym przedsiębiorcom przez cały okres prowadzenia działalności gospodarczej. Wskazania respondentów dotyczące cech charakteru odzwierciedlają, jakim wyzwaniom muszą sprostać osoby zakładające i prowadzące własną działalność gospodarczą na obszarze badanej gminy. Jednym z zadań jest stawianie przed sobą celów, które będą wytrwale realizowane. Pracowitość i motywacja dają sposobność osiągnięcia zamierzonych rezultatów. Do realizacji planów niezbędna jest znajomość rynku oraz szeroka wiedza na różnorodne tematy. Kreatywność oraz pomysłowość są konieczne przy poszukiwaniu nowych pomysłów i rozwiązań dotyczących poszerzania działalności i rozwoju przedsiębiorstwa. Nieodzownym elementem jest również umiejętność podejmowania ryzyka, brak tej cechy całkowicie uniemożliwia sprawne funkcjonowanie przedsiębiorstwa.

\section{Literatura}

Adamkiewicz-Drwiłło H.G., Uwarunkowania rozwoju przedsiębiorczości. Determinanty i narzędzia zdobywania przewagi konkurencyjnej, PWN, Warszawa 2007.

Audretsch D.B., Obschonka M., Gosling S.D., Potter J., A New Perspective on Entrepreneurial Regions: Linking Cultural Identity with Latent and Manifest Entrepreneurship, „Small Business Economics" 2016, vol. 47, no. 2.

Batstone C., Perry G., Polsaram P., Thai Service Sector Smes: Is Tacit Knowledge the Key Entrepreneur Success Characteristics?, 16th Annual Conference of Small Enterprise Association of Australia and New Zealand, 2003.

Begley T. Boyd D., Psychological Characteristics Associated with Performance in Entrepreneurial Firms and Smaller Businesses, „Journal of Business Venturing” 1987, vol. 2.

Bird B., Entrepreneurial Behavior, Glenview, Scott, Foresman \& Company, Illinois 1989.

Brockhaus H.R., Risk Taking Propensity of Entrepreneurs, „Academy of Management Journal" 1989, vol. 23, no. 3 .

Brockhaus R.H., Horowitz P.S., The Psychology of Entrepreneur, [w:] The Art. and Science of Entrepreneurship, D. Sexton, R. Smilor (red.), Ballinger Publishing Company, Cambridge Massachusetts 1986.

Cacciotti G., Hayton J.C., Fear and Entrepreneurship: A Review and Research Agenda, „International Journal of Management Reviews" 2015, vol. 17, no. 2.

Carland J.C., Carland J.W., Stewart W.H., Seeing What's Not There: The Enigma of Entrepreneurship, ,Journal of Small Business Strategy” 1996, vol. 7, no. 1.

Carland J.W., Hoy F, Boulton W.R., Carland J.C., Differentiating Small Business Owners from Entrepreneurs, „Academy of Management Review” 1984, no. 9.

Chrisman J.J., Estimating The Extent Entrepreneurial Intentions Become Reality: A Note, United States Association for Small Business and Entrepreneurship, „Annual National Conference" 1997, no. 14. 
Davidsson P., Determinants of Entrepreneurial Intentions, RENT IX Workshop in Entrepreneurship, Research, Piacenza, Italy 1995.

Dionco-Adetayo E.A., Factors Influencing Attitude of Youth Towards Entrepreneurship, „International Journal of Adolescence and Youth" 2006, vol. 13, no. 1/2.

Domurat A., Przedsiębiorczość a kreatywność i innowacyjność, [w:] Innowacyjna przedsiębiorczość: teorie, badania, zastosowania praktyczne, perspektywa psychologiczna, A. Strzałecki (red.), Wydawnictwo SWPS, Warszawa 2011.

Franken R.E., Psychologia motywacji, Gdańskie Wydawnictwo Psychologiczne, Gdańsk 2005. Górski J., Sierpiński W., Historia powszechnej myśli ekonomicznej 1870-1950, Warszawa 1987. Gruszecki, T. Przedsiębiorca w teorii ekonomii, Cedor, Warszawa 1994.

Grzegorzewska-Mischka E., Współczesne uwarunkowania rozwoju przedsiębiorczości w Polsce, Oficyna Wydawnicza SGH, Warszawa 2010.

Heilbroner R.L., Wielcy ekonomiści. Czasy, życie, idee, PWE, Warszawa 1993.

Hisrich R.D., Entrepreneurship/Intrapreneurship, "American Psychologist” 1990, vol. 45, no. 2.

Hull D.L., Bosley J.J., Udell G.G., Renewing the Hunt for The Heffalump: Identifying Potential Entrepreneurship by Personal Characteristics, ,Journal of Small Business Management" 1980, vol. 18. no. 1.

Kaczmarek M., Cechy osobowości jako predykator motywacji i skuteczności działań przedsiębiorczych, „Problemy zarządzania” 2014, t. 12, nr 1(45).

Kirzner I., The Entrepreneurial Process, „The Environment of Entrepreneurship” 1984.

Kolb C., Wagner M., Crowding in or Crowding Out: The Link Between Academic Entrepreneurship and Entrepreneurial Traits, „The Journal of Technology Transfer” 2015, vol. 40, no. 3.

Krajewski K., Determinanty rozwoju małych i średnich przedsiębiorstw, IPiS, Warszawa 1999.

Kraśnicka T., Koncepcja rozwoju przedsiębiorczości ekonomicznej i pozaekonomicznej, Wydawnictwo Akademii Ekonomicznej w Katowicach, Katowice 2002.

Kraśnicka T., Uwarunkowania rozwoju przedsiębiorczości - podejście wielowymiarowe, [w:] Przedsiębiorstwo $w$ procesie transformacji, K. Jaremczuk (red.), WSAiZ „Zeszyty naukowe" nr 5, Przemyśl 2000.

Łaguna M., Przekonania na własny temat a aktywność celowa. Badania nad przedsiębiorczościa, Gdańskie Wydawnictwo Psychologiczne, Gdańsk 2010.

McClelland D.C., The Achieving Society, Princeton, Van Nostrand 1961.

McGrath R.G., McMillan I.C., Sheinberg S., Elitists, risk-takers, and rugged and non-entrepreneurs, ,Journal of Business Venturing” 1992, no. 7.

Milian L., Przedsiębiorczość i przedsiębiorstwo turystyczne. Socjologiczne uwarunkowania sukcesu, Wydawnictwo Politechniki Częstochowskiej, Częstochowa 2000.

Osborn E., Słomczyński K.M., Open for Business. The Persistent Entrepreneurial Class in Poland, IFiS Publishers, Warszawa 2005.

Ostromęcki A., 2006, Wywoływanie postawy twórczej w procesie rozwoju przedsiębiorczości, [w:] Uwarunkowania przedsiębiorczości - aspekty ekonomiczne i antropologiczno-spoteczne, K. Jeremczuk (red.), PWSZ, Tarnobrzeg 2006.

Otoliński E., Istota i kreowanie przedsiębiorczości, „Przegląd organizacji” 1996, nr 9. 
Pawlak J., Wybrane psychologiczne determinanty przedsiębiorczości absolwentów $w$ świetle koincydencji teorii rozwoju, „Nierówności Społeczne a Wzrost Gospodarczy” 2015, nr 42(2).

Perry-Smith J.E., Shalley C.E., The Social Side of Creativity: A Scientific and Dynamic Social Network Perspective, „The Academy of Managenent Review” 2003, vol. 28, no. 1.

Piecuch T., Przedsiębiorczość podstawy teoretyczne, C.H. Beck, Warszawa 2013.

Pietras H., Przedsiębiorczość w warunkach gospodarki rynkowej, [w:] Przedsiębiorczość w teorii i praktyce gospodarczej, W. Grzybowski (red.), Lublin 1994.

Rotter J.B., Generalized Expectancies for Internal Versus External Control of Reinforcement, „Psychological monographs: General and applied” 1966, no. 80(1).

Skowrońska A., Tarnawa A. (red.), Raport o stanie sektora matych i średnich przedsiębiorstw $w$ Polsce, PARP, Warszawa 2018.

Strzałecki A., Creativity in Design. General Model and Its Verification, „Technological Forecasting and Social Change" 2000, no. 64(2/3).

Strzałecki A., Transgresja polskich menedżerów w warunkach transformacji ustrojowej, [w:] Człowiek wobec wyzwań i dylematów współczesności, A. Aranowska, M. Goszczyńska (red.), Scholar, Warszawa 2006.

Strzałecki A., Czołak D., Osobowościowe i temperamentalne czynniki warunkujące osiąnięcie sukcesu w przedsiębiorczości, „Przegląd Psychologiczny” 2005, nr 48(2).

Strzałecki A., Style twórczego zachowania w przedsiębiorczości, [w:] Innowacyjna przedsiębiorczość: teorie, badania, zastosowania praktyczne, perspektywa psychologiczna, A. Strzałecki (red.), Wydawnictwo SWPS, Warszawa 2011.

Steward Jr. W.H., Roth P.L., Risk Propensity Differences Between Entrepreneurs and Managers: A Meta-Analytic Revive, ,Journal of Applied Psychology” 2001, no. 86.

Studenski R., Studenska A., Predykatory przedsiębiorczości, [w:] Przedsiębiorczość źródła i uwarunkowania psychologiczne, Z. Ratajczak (red.), Difin, Warszawa 2012.

Szewczyk W., Encyklopedia psychologii, Wydawnictwo Fundacja „Innowacja”, Warszawa 1998.

Tyszka T., Psychologia zachowań ekonomicznych, PWN, Warszawa 1997.

Turek D., Przedsiębiorca a pracownik przedsiębiorczy. Podobieństwa i różnice profili kompetencyjnych i ich implikacje dla procesów zarządzania. Perspektywa charakterystyk podmiotowych, [w:] Potencjał ludzki w rozwoju przedsiębiorczości indywidualnej i korporacyjnej, B. Jamka (red.), Difin, Warszawa 2012.

Wiatrak A.P., Pojęcie przedsiębiorczości, jej cele i rodzaje, [w:] Uwarunkowania rozwoju przedsiębiorczości - szanse i zagrożenia, K. Jaremczuk (red.), PWSZ, Tarnobrzeg 2003.

Zhao H., Seibert S.E., Lumpkin G.T., The Relationship of Personality to Entrepreneurial Intentions and Performance. A Meta-Analytic Review, „Journal of Management”2010, vol. 36, no. 2 .

\section{Materiały elektroniczne}

Główny Urząd Statystyczny, http://stat.gov.pl [dostęp: 25.02.2026].

Centralna Ewidencja Działalności Gospodarczej, https://prod.ceidg.gov.pl [dostęp: 25.02.2026]. 